\title{
Technical Review of Fin Addition Analysis of Air Intake Valve on Gas-Oil Fuel Engine
}

\author{
Semin $^{1}$, Linggar Palang Aras RFC ${ }^{2}$, Beny Cahyono ${ }^{3}$, Nilam Sari Octaviani ${ }^{4}$
}

\begin{abstract}
-modification of single-fuel diesel engine into dual-fuel diesel engine has been done by researchers to solve the problem of depletion petroleum reserves. Even the problem petroleum reserves are projected to be exhausted in the next 50 years. Gas-Oil fuel engine focus on solar-CNG as a fuel. Explanation of the difference in the fuel ratio of diesel engines with Gas-Oil fuel diesel engines has considerable differences. The factors that are discussed here are the factors of mixing air and fuel. The amount of fuel in the Gas-Oil fuel diesel engine causes an increase in the gas fuel mass flow rate (CNG), although with the addition of fuel gas, the mass flow rate of diesel oil is reduced. In this paper, the Gas-Oil fuel engines research and development fueled using solar-CNG are highlighted to keep the performance of the engine. Modification focused on air intake valve to give maximum turbulent flow ratio and effect on increasing Gas-Oil fuel engine performance. The high activities for future Gas-Oil fuel engines research and development to meet future Gas-Oil fuel engine solar-CNG is recorded in the paper.
\end{abstract}

Keywords—air intake valve, Gas-Oil fuel engine, CNG, turbulent flow

\section{INTRODUCTION}

$\mathrm{T}_{\mathrm{be}}$ he development of alternative sources in the context of reducing dependency on fuel oil has become important government agenda on National Energy Policy. The policy is translated in the form of efforts to empower existing energy sources. The use of gas fuel (BBG) as an energy source is one of the many efforts that can to be made in order to replace fuel oil. Gas fuel is any type of gas fuel, such as natural gas and gas from petroleum [1].

Specifically, alternative source to replace fuel oil is compressed natural gass (CNG). Which most of the chemical element consists of methane (CH4) and the rest are methane, propane, butane, penthana, and carbon monoxide. The composition and characteristics of the gas will vary greatly from one source to another, which affects the stoichiometric conditions. Compressed natural gas has some deficiencies, which is the phase in the room temperature so it will be difficult to make the gass storage and mobility. In addition, natural gas has a smaller energy density energy than diesel, methanol, gasoline, or other liquid hydrocarbon fuels. Compressed natural gas (CNG) is an alternative fuels besides gasoline or diesel [2]. This fuel is more cleaner than fuel oil. When compared to fuel oil due to its environmentally friendly exhaust emissions. CNG is made by compressing methane (CH4) extracted from natural gas. The gas is mixed with fresh air in air intake manifold (or

Semin, Department of Marine Engineering, Institut Teknologi Sepuluh Nopember, Surabaya 60111, Indonesia, Email : seminits@yahoo.com

Linggar Palang Aras RFC, Department of Marine Engineering Institut Teknologi Sepuluh Nopember, Surabaya 60111, Indonesia, Email : palangaras5@gmail.com

Beny Cahyono, Department of Marine Engineering, Institut Teknologi Sepuluh Nopember, Surabaya 60111, Indonesia, Email : benyjtsp98@gmail.com

Nilam Sari Octaviani, Department of Marine Engineering, Institut Teknologi Sepuluh Nopember, Surabaya 60111, Indonesia, Email : nilam.octaviani@gmail.com injected into the cylinder) and inserted into the cylinder ignited by a small amount of diesel fuel when the piston approaches the end of the compression step (TDC)[3].

The advantage using CNG on diesel engine emissions produces particulate matters (PM), hydrocarbons (HC), carbon monoxide (CO), carbon dioxide (CO2) and nitrogen oxide (NOx), which decreases significantly, but thermal efficiency decreases. From 2010 to 2015 many studies show that there is a significant reduction in emissions in the presence of CNG-Diesel and other alternative fuels when compared to conventional diesel engines [4-5].

Inadequate processing and utilization makes CNG one of the great potentials for alternative energy [6]. CNG was introduced as an alternative fuel because of its emissions produced [7]. CNG has many benefits and has almost no negative impact that provides the perfect reason to become the next fuel for our world to rely on. But the utilization is not maximized yet [5-9].

\section{AIR INTAKE VALVE}

Modifications that can be made by mosifying change of shape in some parts of the diesel engine element, Which are bit more capable enough to improve the performance of the engine. Modifications made can be the reduction of weight on the flywheel which resulted in an increase motor rotation, reduce the height of the cylinder head which aims to increase the compression ratio in the combustion chamber which will also increase the engine output power. In addition to both types of modifications there is a modifying method that is relatively easy to do, making changes in the intake manifold on diesel engines. Air is very needed at combustion chamber so intake manifold plays an important role for free air needed by engine from the environment [10].

The amount of air that can enter the combustion chamber greatly affects the performance of diesel engines. The amount of air entering the cylinder at the time of the suction step is theoretically equal to the volume of the piston step from the top dead point to the bottom dead point or from TDC to BDC. In fact, there 
are some deviations that cause the volume of air entering the cylinder to be smaller than the volume of the combustion chamber. The aberrations among others are caused by factors such as air pressure, air temperature, resiGas-Oilgas residue, length of intake manifold and shape of intake manifold. The amount of actual air volume entered into the cylinder can be expressed in a comparative figure between the volume of air entering with the piston step volume from the top dead point to the bottom dead point. This condition theorically defined as "Volumetric Efficiency" [11]. If the air intake valve opening is set tight then the valve opens earlier and closes for longer which means that the entire suction step gets full valve passage so that suction requires less work and the combustion chamber can be filled with more air (high volumetric efficiency) [10-11].

Valves are parts of a component that has a mechanism of arranging the opening and closing of air in and out, in this case inside the combustion chamber. The valve is a dynamic device made of high temperature resistant metal mounted on the cylinder head. Valves mounted on the cylinder head consist of inlet valve and exhaust valve. The inlet valve is a valve used to open and close the inlet so that air can enter the cylinder, while the exhaust valve is a valve used to open and close the drain so that the combustion gases can be wasted out of the combustion chamber. Each cylinder has one inlet and one exhaust valve, but there are also cars with four valves on each cylinder and even up to six valves [12].

The type of valve on the head (OHV) is a valve driving mechanism where the knock shaft is in the cylinder block so as to move the valve, some intermediate tools are tappet (valve lifter), push rod and rocker arm, while for system valve type the knock shaft on the cylinder head (OHC) whether one axle or two axle knock requires a simple intermediate from the shaft knock (cam shaft) directly to the trigger to the valve, some even from the shaft knock directly move the valve without the trigger [10-12].

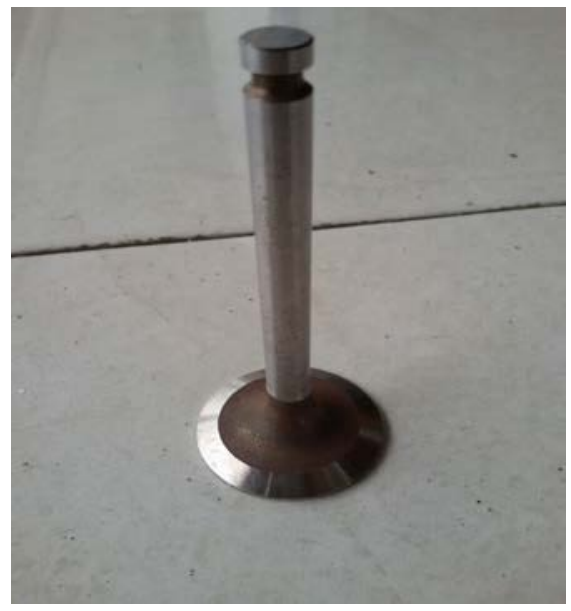

Figure.1. Air Intake Valve

The valve mechanism consists of :

a) Materials

Made of iron and steel alloy material with other elements, e.g. with charcoal, silicon, nickel chrome, tungsten, manganese. For the intake valve is made of nickel chrome alloy and for exhaust valve made of silicon steel alloy.

b) Functions

* Open and close the way of gas / air to combustion chamber and disposing of burned gas residue at the specified time.

* Prevent leakage of compression and burst of combustion.

c) Characteristics

* It should be light and has a cone shape of $45^{\circ}$ or $30^{\circ}$ at the valve seat.

* Must be strong and high vibration resistant.

* High durability and when the valve is closed, the valve will attach tightly to the position of the valve.
Valve is a very important component part of the internal combustion engine in which it plays an important role in the air supply path and emission path or exhaust gas from inside the combustion chamber. The process and working principle of this valve has an effect and a direct impact on the performance parameters engine (power, torque, fuel consumption) and also exhaust emissions. The stress that occurs and received by the valve during its lifetime is affected by valve train dynamics and combustion process pressures. During the combustion process, the temperature received by the valve reaches about $550{ }^{\circ} \mathrm{C}$. While the temperature at the exhaust valve can reach about $700{ }^{\circ} \mathrm{C}-900^{\circ} \mathrm{C}$. As this process takes place naturally, the valve focuses on the stresses and stress loads applied to the camshaft. So that, the valve's material can be damaged in the form of fatigue strength stress. Damage to the valve can occur in 3 cases. The first can occur in the valve head area where it is caused by radial cracks that occur due to very high temperature differences. This is commonly called thermal fatigue failure. The second can occur in the area around the valve seat where it is caused by transversal cracks.because of the influence of mechanical bending 
stresses. While the third case is common in the groove area caused by stress concentration that occurs due to high work pressure. The phenomenon of oxidation and corrosion can also cause damage to the valves inside the machine [13].

Turbulence airflow that can be a swirl ratio has a relationship with the temperature and turbulence of the flow itself. This parameter has an important role in explaining the burning and emission patterns in the machine. In a diesel engine, a swirl stream is used to accelerate the mixing of incoming air with the fuel injected by the fuel injector. Turbulence itself is a state of random fluid flow. The fluid velocity at a point is always changing over time. In this case, streams continuously shaped large vortices that then split into smaller vortices and eventually disappear. Fluid particles that are at first far apart can be brought close to each other because of the vortex in the turbulence flow. As a consequence heat exchange, mass, and momentum become very effective. This effective mixing will cause large diffusion coefficients for mass transfer and heat momentum, but energy loss in turbulence flow will also be greater than laminar flow. This happens because the vortices that occur work against viscous stress, so that the energy contained in the round will be dissipated into heat.

Both the exhaust valve and the intake valve are important components of internal combustion engines and which control the flow of fresh air and the combustible gas in and out of the engine cylinder. In a four-stroke diesel engine during the suction valve, the suction step remains in open condition allowing fresh airflow go inside the combustion chamber and the exhaust valve is kept closed. In the compression step, both valves remain and are closed. At the end of the exhaust step, the exhaust valve is opened to remove the burning gas inside the combustion chamber. The whole operation is done by valve mechanism. The valve mechanism consists of components such as valves, valve sheets, valve guides, valve seals, spring valves, retainers and others. These components are installed properly in the cylinder head [14].

In previous research, the explanation of the difference in the fuel ratio of diesel engines with Gas-Oil fuel engines has considerable differences. The factors that are discussed here are the factors of mixing air and fuel. The amount of fuel in the Gas-Oil fuel engine causes an increase in the gas fuel mass flow rate (CNG), although with the addition of fuel gas, the mass flow rate of diesel oil is reduced. Evident in the research using the loading resulted in reduced air and fuel ratio[15]. This is due to a decrease in the initial injection and the injection duration to the engine combustion chamber. The condition of the engine with the addition load requires the machine to work with even more weight to balance the large loads as well. So when the greater power is generated from burning more fuel, and fuel is fueled by diesel fuel because CNG fuel is constantly introduced at a pressure of 2 bar so that the addition of CNG causes a better mass flow rate to cover the influence of the duration of injection against the greater the burden. So as a result of the addition of fuel gas (CNG), then the power generated is able to balance the large load given to the machine.
Based on research before using modified water intake valve the following results are obtained[16-17] :

- The fin model on the air intake valve produces a better swirl flow for a better thermal efficiency.

- The CO emission level decreases with the addition of the fin to the air intake valve.

\section{GAS-OIL FUEL DIESEL ENGINE}

Conventional diesel engine technology which extremely more sophisticate with the aim to achieve the highest efficiency so emerging various types of engines. The highest efficiency that still can not be achieved causes the need, continue to innovate and give correction the deficiencies that are still possible for better conditions. One form of innovation that has been made is the type of dual-fuel engine. Dual-fuel engine is one of the studies that is considered to cover some shortcomings of other types conventional engines. Research on dualfuel engine has been done a lot. Dual-fuel engines can improve engine efficiency and also produce lower emissions than other conventional engines [18].

In normal diesel engine modifications to Gas-Oil fuel, pure air inhaled will be mixed with gas, so only a small amount of diesel fuel is required for explosion. Diesel fuel gas mixtures mostly use the intake valve to insert gas together with pure air. Operation in Gas-Oil fuel mode can reduce nitrogen oxide emissions (NOx) approaching 85\%. In addition, when operating with natural gas and low-sulfur fuel, the dual-fuel diesel engines produce SOx content levels and almost zero charcoal.

In single fuel systems, diesel engines work by sucking pure air from the outside. However, for Gas-oil fuel systems, which enter the combustion chamber is not only pure air. The air will come in along with some gas fuel. The air mixing and fuel gas mechanism may occur in a mixer / blender or by using a high pressure gas injector which directly injects the gas into the combustion chamber, and uses a low pressure gas injector placed in the mouth of the intake manifold and will only inject gas when the suction valve is open. As the compression step on the diesel engine, the temperature and pressure of the gas-fuel air mixture will increase. However, that is not enough to make the mixture burn because the fuel gas has its own burning temperature higher than diesel.

Therefore it takes a certain amount of diesel fuel injected into the combustion chamber to start combustion. The combustion will increase the pressure and temperature in the combustion chamber, so the fuel gas becomes burned. The method of diesel injection into the combustion chamber maintains the original system of the diesel engine [15].

In Gas-Oil fuel operation system or Gas-Oil fuel engine, combustion ideally consists of a diesel fuel flame that develops through the dominant air mixture and mixed gas mixing mixture occurring in the combustion chamber. Premix air and gas fuel burn right on the diesel flame and the combustion beginning with the diesel 
flame and spreading through the remaining air and gas fuel mixture. During the compression step, the mixed temperature and fuel pressure are greatly increased, forming a pre-ignition reaction environment. During this phase, partial oxidation products may form at the end of compression to trigger mixed air combustion and diesel fuel combustion. The initial spread of diesel fuel is strongly influenced by turbulence, vortex, and squish inside the cylinder. The times where diesel engine is converted into a Gas-Oil fuel system occurs by introducing natural gas as a fuel source that is burned simultaneously. In Gas-Oil fuel engines with conventional injection systems, up to $86 \%$ substitution rates by energy have been proved [18-19].

Where, this compressed natural gas contains more than $90 \%$ methane. In terms of price, CNG is much cheaper than other gas fuels because it is not through liquefaction and other processes [20]. Therefore, the application of a Gas-Oil fuel system is expected to save on fuel consumption and reduce exhaust emissions generated by engines compared with a single fuel system [21].
Research and development of Gas-Oil fuel diesel engines is increasing every year, not only used for experimental processes but also has been developed in the field of industry and transportation [22]. The application of Gas-Oil fuel engine is very promising in the environmental and economic point of view but still technically constrained on the decrease in performance in the form of power, torque, cylinder pressure and thermal efficiency as well as producing knocking [2224].

One of the causes of decreased performance in Gas-Oil fuel engines is the heat value of gas and air mixture lower than the mixture of diesel and air. In addition, the mixture of gas and air fuel in Gas-Oil fuel engines is lean (poor fuel concentration). This causes diesel fuel that acts as a spark ignition difficult to burn gas and air mixture into the combustion chamber and affect the rate of slow burning and slow flame propagation speed when the combustion process occurs. As a result, the heat wasted during the combustion process increases, causing the engine's thermal efficiency to decrease [24].

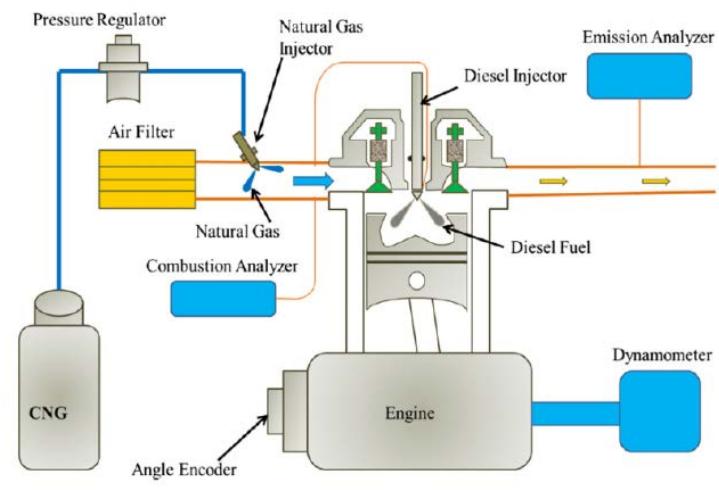

Figure.2. Scheme of Gas-Oil fuel Engine[24].

The movement of air and gas into the combustion chamber is one of the important factors for improving the combustion process in Gas-Oil fuel engines in order to improve engine performance [25]. By increasing the turbulent flow instensity and increasing the speed of air and gas flow in the combustion chamber prior to the combustion process. Research explains that turbulent flows in the combustion chamber affect the combustion velocity[26]. In mixing air and fuel with the laminer flow, the burning speed that occurs tends to be slow while it will increase when turbulent flow. This is because turbulent flow increases the surface (area of burning) so as to increase heat transfer to gas and air mixture on Gas-Oil fuel engine. Turbulence in the combustion chamber is also able to improve engine efficiency [24-26].
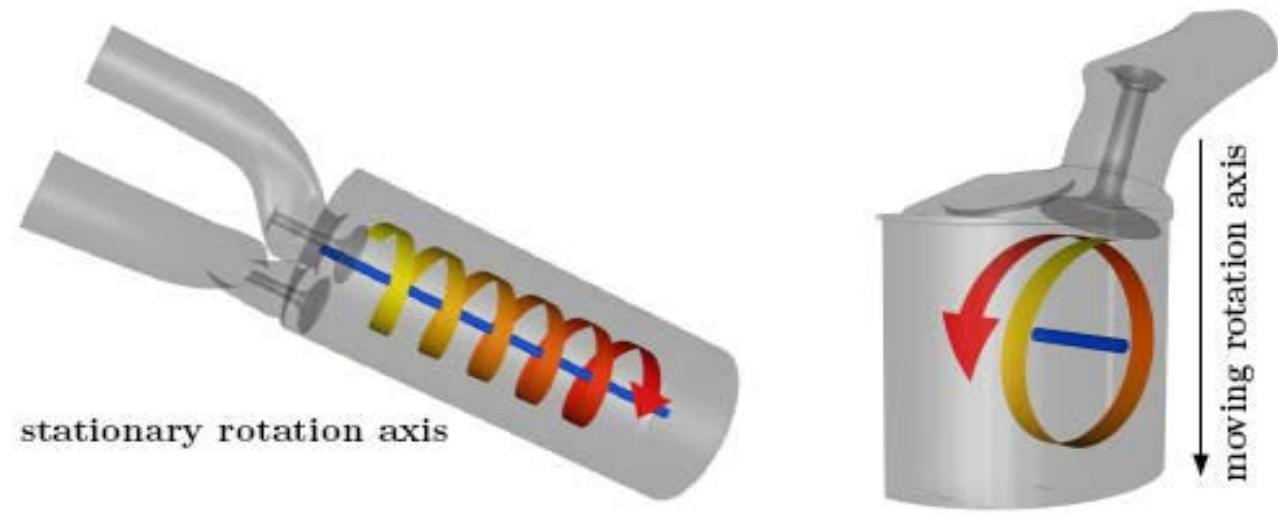

Figure.3. Turbulent Flow Illustration 
In general, the rotational flow is formed due to an angular tendency between the axis of the rotational base on the inside of the cylinder with the cylinder axis. The magnitude of this angle depends on the intake runner or machine port inlet, the ratio of bore and stroke, the shape of the combustion chamber and the geometry of the suction valve [27]. Valves are engine components associated with airflow. To form a rotation flow in the combustion chamber, it is necessary to develop the suction valve. In this study, we will analyze the influence of the development of the fin intake valve on the diesel engine to the airflow generated in the combustion chamber, the mixing of air and fuel and its effect on the combustion characteristics of Gas-Oil fuel diesel engines using CNG and Solar fuels [28].

Several studies and researches on the conversion of diesel-fueled diesel engines to dual-fuel engines (diesel and gas) have been done, both in computational and experimental simulations. The results of these conversions have an effect on the combustion process and engine performance. This is due to the different characteristics of the fuel used. Table 1 shows the property differences between gas and diesel fuel engine. The difference in fuel properties is what causes the addition of natural gas in the combustion chamber will affect the changes in performance and combustion process on Gas-Oil fuel engines. Natural gas characteristics used in ignition engines, spark ignition is good, while its use in compression ignition engine is still under development. The use of natural gas in diesel engines evolves from poor ignition characteristics due to high auto ignition temperature and low cetane counts compared to diesel. Therefore, an ignition source is always required to naturally ignite natural gas in a cylinder [24].

Table 1.

Psychochemical Properties of Diesel Fuel and Natural Gas

\begin{tabular}{|c|c|c|}
\hline Fuel Properties & Natumal Gas & Diesel \\
\hline Low heating value $(\mathrm{MJ} / \mathrm{kg})$ & 48.6 & 42.5 \\
\hline $\begin{array}{l}\text { Heating value of stoichiometric mixture } \\
(M J / \mathrm{kg})\end{array}$ & 2.67 & 2.79 \\
\hline Cetane number & - & 52.1 \\
\hline Octane number & 130 & - \\
\hline Auto-ignition temperature $\left({ }^{\circ} \mathrm{C}\right)$ & 650 & $180-220$ \\
\hline Stoichiometric air/fuel ratio & 17.2 & 14.3 \\
\hline Carbon content (\%) & 75 & 87 \\
\hline
\end{tabular}

In Gas-Oil fuel diesel engines, gas and air mixing process occur when they enter the combustion chamber. The principle of homogenization between air and fuel is the working principle of the otto machine. Furthermore gas and air that have been homogeneous then experience the compression process. At the end of the compression process, when the gas and air have been at a certain pressure and temperature, diesel fuel is injected into the combustion chamber resulting in the combustion process. This is the working principle of diesel engines in general. The advantages of Gas-Oil fuel engine is if there is a failure of gas fuel, the engine can still work by switching Gas-Oil fuel operational mode into a conventional diesel engine that rely solely on diesel fuel. While the drawback is the engine is very dependent on the availability of diesel fuel for Gas-Oil fuel engine working system remains [29-51].
The efficiency and bsfc ratio of diesel and Gas-Oil fuel engines is shown in Figure 4 and Figure 5. At low loads, the efficiency is lower for Gas-Oil fuel operations compared to normal diesel operations while bsfc is higher for Gas-Oil fuel operations. This may be due to slower burning rates and poor gas fuel utilization in the combustion chamber. In addition, mass-specific heat of natural gas is higher than pure air and higher than diesel vapor. It can also play a role by reducing the burning temperature and consequently slowing down the combustion process. Trend improved on medium and high loads. It is observed that ignition delay decreases at high loads in Gas-Oil fuel operations, which encourages faster combustion. In addition, the diesel injection time is increased for Gas-Oil fuel compared to diesel on three top loads by 2 to 3.5 degrees. The timing is advanced and has a significant impact on engine efficiency [3952]. 


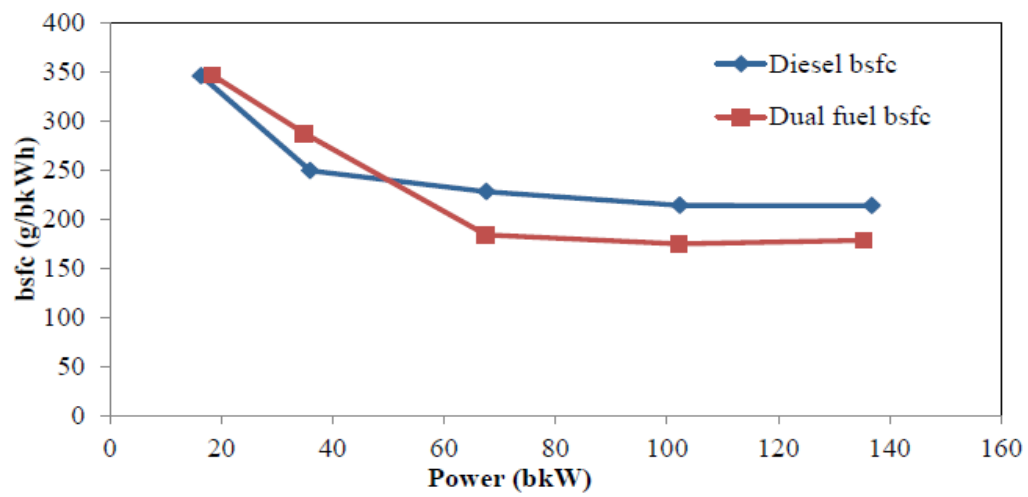

Figure.4. Engine’s BSFC Graph

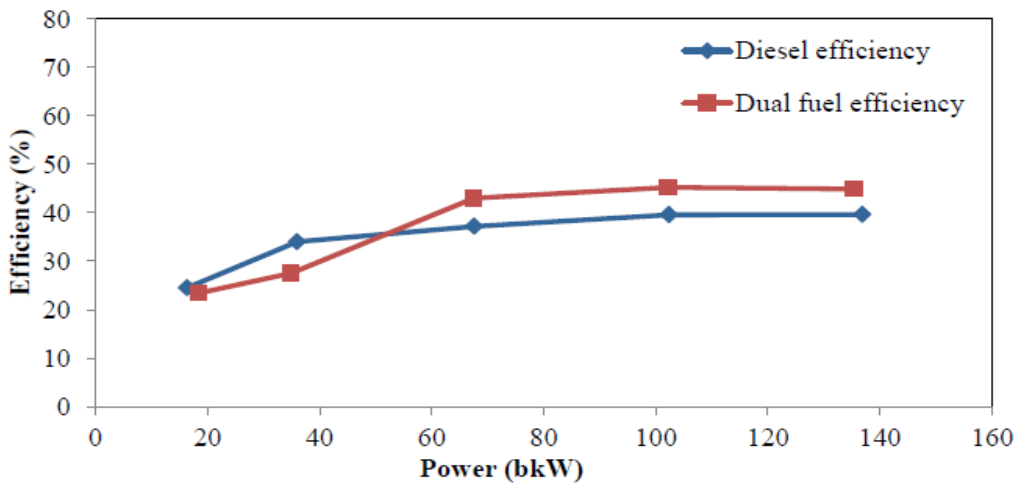

Figure.5. Engine’s Efficiency Graph

To generate air swirl inside combustion chamber of a direct ignition diesel engine, before enter combustion chamber, an attempt is made to modify some possible changes in an air intake valves without disturbing the properties of valve material, which ensures an improved combustion and a noticeable improvements in emission levels at its exhaust gases. In order to get better results on engine performance and most suitable modifications has been tried to make grooved air intake valve [45-53].

Form the best results in air intake valve modification based on research [50-53], then it makes some experiment for the results. The best valve modification as shown in the figure 6 . Then we get some graph from the experiment.

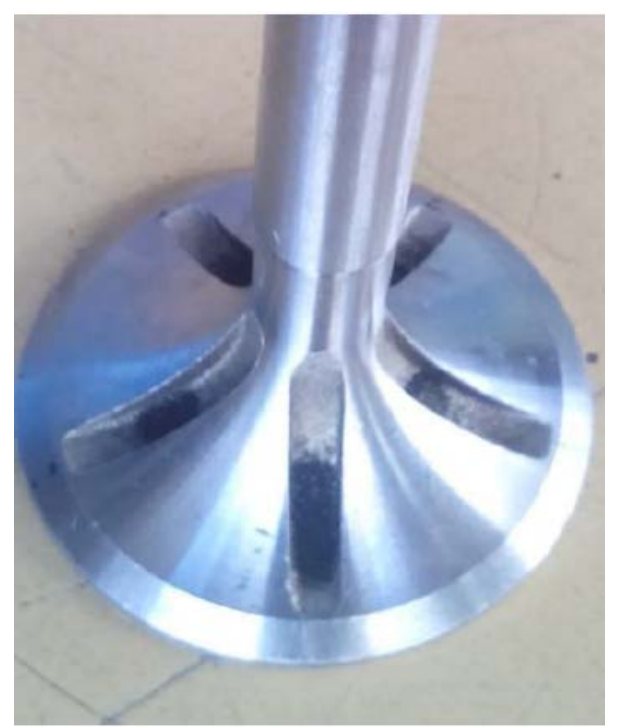


Figure.6. 5-grooved Modification on Air Intake Valve

The addition of modifications to the intake valve was previously done to make better turbulent flow when entering the combustion chamber. Turbulent flow that occurs in the combustion chamber will raise the mixture of air and fuel or air fuel ratio so that combustion that occurs when step effort will be better. This results in diesel engine performance will increase when compared with the use of regular valve.

In the brake thermal efficiency vs load graph above, as shown in the figure 7 . It is found that the modified intake valve is higher than ordinary valve. This can occur due to differences in output and power input on the machine.
At $60 \%$ loading $(1.5 \mathrm{~kW})$, the highest value is obtained because it corresponds to the compression ratio and the velocity of the airflow at the time of mixing the air with the fuel. However, in $100 \%$ loading ( $2.5 \mathrm{~kW}$ ), the brake thermal efficiency value of intake valve modifications decreased drastically to the normal valve efficiency because the engine at the time was working heavily so that the heat losses on the cylinder wall were greater. It is also influenced by the cooling water temperature and heat loss at the exit temperature when the exhaust valve works in the high lift state.

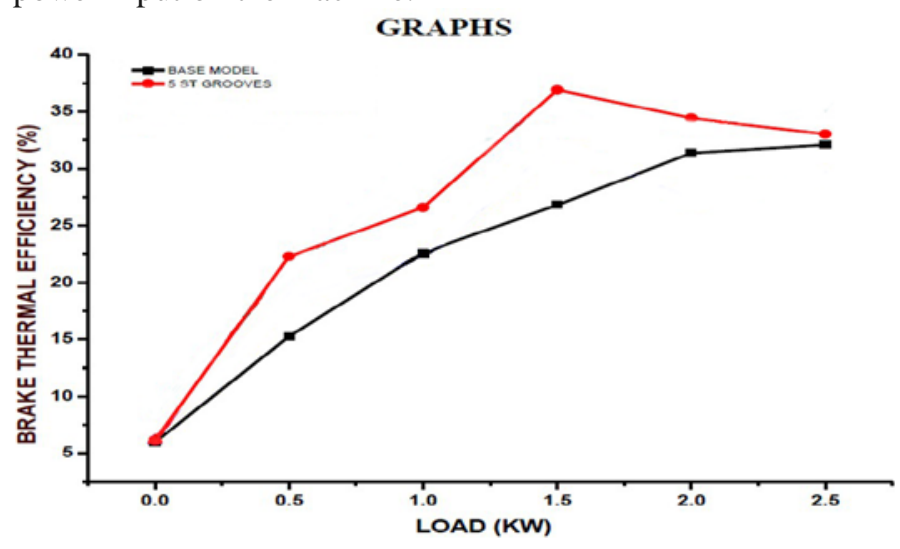

Figure.7. Brake Thermal Efficiency vs Load

In the Specific Fuel Consumption (SFC) versus load as shown in the figure 8 , it was found that when loading up to $80 \%(2 \mathrm{~kW})$ the SFC value in the modified intake valve is lower than the value in the regular intake valve. This happens because the addition of modified intake valve causes air turbulansi into the combustion chamber better so that mixing the air faster makes the fuel flow rate decreases. So at the time of loading $80 \%$ ( $2 \mathrm{~kW}$ ), causing the SFC value to increase again because of the power required by the machine increases because of the load given.

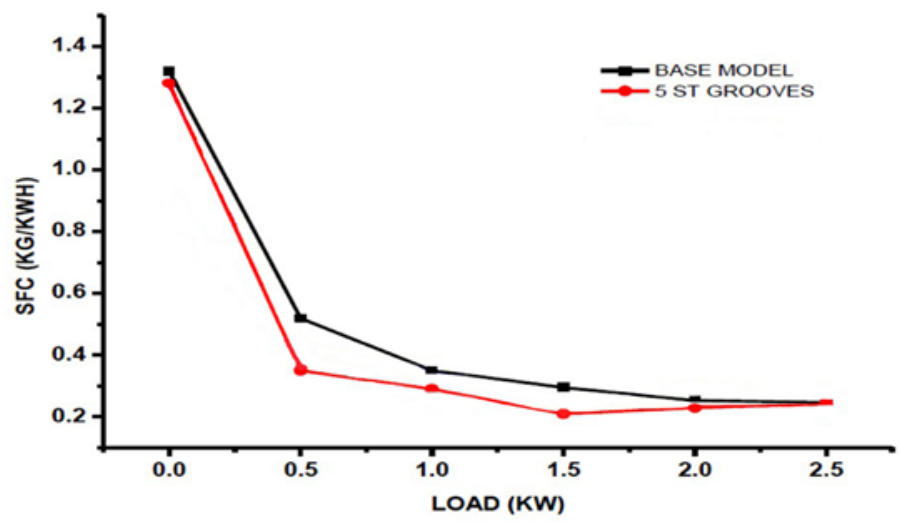

Figure.8. SFC vs Load

In the $\mathrm{A} / \mathrm{F}$ ratio vs load chart as shown in the figure 9, the value obtained on the intake valve modification is higher than that of the regular valve. This is because the addition of modifications to the intake valve causes the mixing of air in the combustion chamber is more perfect. Turbulansi flow that occurs when air enters the combustion chamber minimizes the air density so that the mixture of air and fuel in the combustion chamber or water fuel ratio becomes higher. 


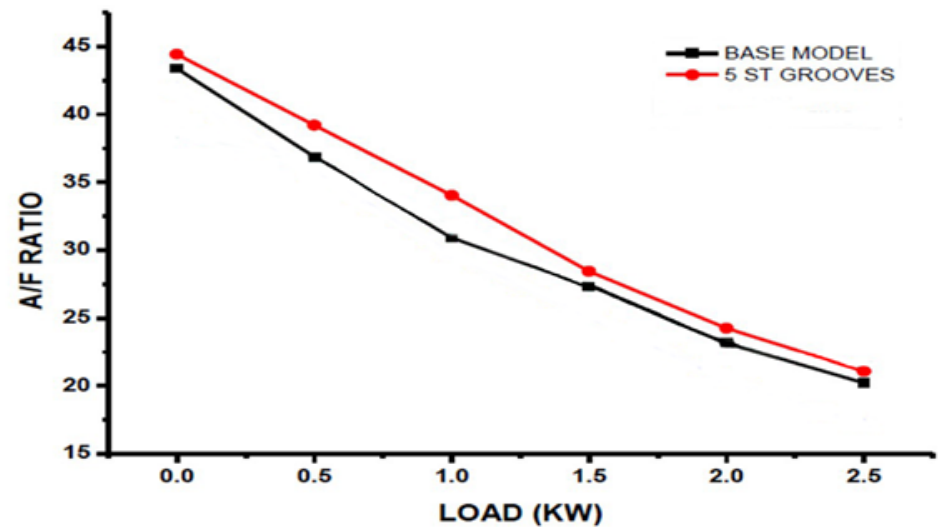

Figure.9. A/F Ratio vs Load

Mechanical efficiency is the ratio of how much power or power generated by the engine due to the expansion of the air in the combustion chamber in the cylinder is converted to output power. This is obviously related to the $\mathrm{A} / \mathrm{F}$ ratio. The higher the $\mathrm{A} / \mathrm{F}$ ratio produced, the higher the mechanical efficiency produced by the engine.

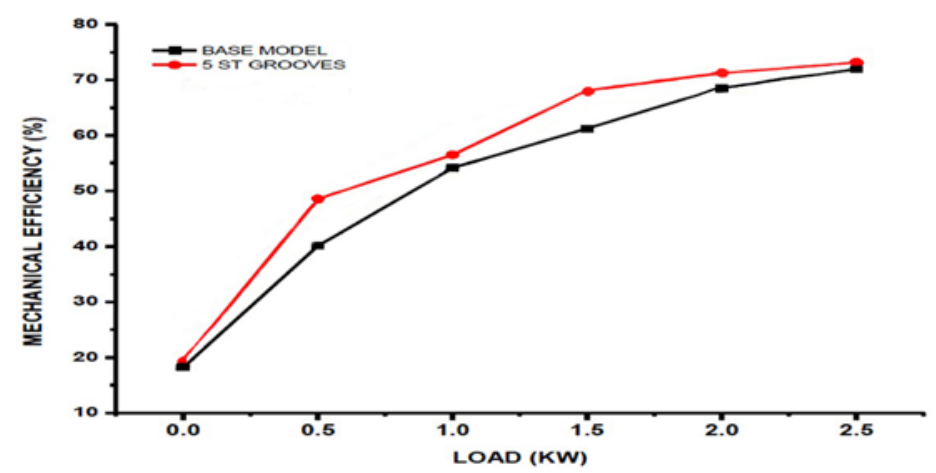

Figure.10. Mechanical Efficiency vs Load

\section{CONCLUSION}

Based on its principle, the working principle of air-fuel mixing between diesel engines with Gas-Oil fuel engines has a difference. In the diesel engine system, mixing of air-fuel takes place inside the combustion chamber or commonly called diffusion combustion. While on a GasOil fuel engine, mixing of air-fuel occurs before entering the combustion chamber or commonly referred to as premix combustion. Research has proved that the performance of Gas-Oil fuel diesel engines decreased when compared with diesel engines. Mainly by using Solar-CNG fuels. but the emissions generated by SolarCNG Gas-Oil fuel engines are much better when compared to diesel engines. For that much researches and study has been done to improve the performance of Gas-Oil fuel diesel engine, and one of them with making modification on air intake valve.

\section{REFERENCES}

[1]. Mulyatno. (2013). Kajian teknis dan ekonomis penggunaan GasOil fuel system (LPG-Solar) pada mesin kapal nelayan tradisional, e-Jurnal Departemen Teknik Perkapalan Universitas Diponegoro. Semarang.

[2]. Yoko, D. and Sudarmanta, B. (2016) Studi Eksperimen Unjuk Kerja Mesin Diesel Menggunakan Sistem Gas-Oil fuel Solar - Gas
CNG dengan Variasi Tekanan Injeksi Gas dan Derajat Waktu Injeksi, 5(2), pp. 604-609.

[3]. Cahyono B., Nugroho T.F., Mardhi, Bakar R.A., (2016), Effect of swirl generator intake manifold on engine performance using ethanol/gasoline blend, Asian Journal of Applied Science, Vol 04 (06).

[4]. Arifin Siagian and Mawardi Silaban. (2011). Performa dan Karakteristik Emisi Gas Buang Mesin Diesel Berbahan Bakar Ganda, Jurnal Teknik Mesin, 13(1), pp. 49-54. doi: 10.9744/jtm.13.1.49-54.

[5]. Ishak Aris. (2015). CNG-diesel Gas-Oil fuel engine : a review on emissions and alternative fuels, pp 6-7.

[6]. Altenpohl, Rogner H. (1988). Compressed Natural Gas (CNG) Potential Applications For Advanced Transportation Tanks And Vehicle Systems. Laxenburg. Austria.

[7]. Narain, U. and Krupnick, A. (2007). The Impact of Delhi's CNG Program on Air, Resources for the Future Discussion Paper, (February). doi: 10.2139/ssrn.969727.

[8]. Imran S., Embrson D.R., Ihracska B., Wen D.S., Crookes R.J., Korakianitis T., (2014), Effect of pilot fuel quantity and type on performance and emissions of natural gas and hydrogen based combustion in compression ignition engine, International Journal Hydrogen Energy 39 (10), pp 5163-5175.

[9]. Semin and Bakar R.A., (2008), A technical review of compressed natural gas as an alternative fuel for internal combustion engines, American Journal of Engineering and Applied Sciences 1, pp 302311.

[10].Sinaga, D. F., Sanuri, S. and Zuhdi, A. (2014). Pengaruh Perubahan Bentuk Intake Manifold Terhadap Unjuk Kerja Motor Diesel Dengan Metode Simulasi, Jurnal Teknik Pomits, 3(1), pp. 30-33. 
[11].Sampurno, S. (2006). Pengaruh variasi penyetelan celah katup masuk terhadap efisiensi volumetrik rata-rata pada motor diesel isuzu oanther C $223 \mathrm{~T}$.

[12].Pratama, A., Ariana I. M. (2008). Studi Modifikasi Intake Valve Dengan Penambahan Sirip Untuk Optimalisasi Swirl Dengan Simulasi CFD. ITS. Surabaya.

[13].Azadi, M., Roozban, M. and Mafi, A. (2013). The Journal of Engine Research Failure analysis of an intake valve in a gasoline engine, 26(spring 2012), pp. 3-9.

[14].Lavhale, Y. K. and Salunke, J. (2014). Overview of failure trend of inlet \&amp : exhaust valve, International Journal of Mechanical Engineering and Technology, 976(3), pp. 976-6359.

[15].Arif, A. et al. (2015). Karakterisasi Performa Mesin Diesel GasOil fuel Solar-Cng Tipe Lpig Dengan Pengaturan, (2013), pp. 1-8.

[16].Hiregoudar, Y. and Shiva, P. (2014). Effect of Inlet Air Swirl On Four Stroke Single Cylinder Diesel Engine Performance, International Journal of Recent Development in Engineering and Technology, 2(6), pp. 95-103.

[17].Yerrennagoudaru, H. and prasad Desai, S. (2015). Generation of Air Swirl through Inlet Poppet Valve Modification and To Enhance Performance on Diesel Engine, IOSR Journal of Mechanical and Civil Engineering, 12(6), pp. 2278-1684. doi: 10.9790/1684-12665465.

[18].Hidayat, Sanuri, and Zuhdi, A. (2013). Kajian Eksperimental Unjuk Kerja Gas-Oil fuel Engine Hasil Modifikasi Dari Diesel Engine. ITS. Surabaya.

[19].Hasannuddin, A. K. et al. (2016). Performance, emissions and lubricant oil analysis of diesel engine running on emulsion fuel, Energy Conversion and Management. Elsevier Ltd, 117, pp. 548557. doi: 10.1016/j.enconman.2016.03.057.

[20].Clarke, Bruyn D. (2012). Vehicle Conversion to Natural Gas or Biogas. OMAFRA Factsheet. Canada.

[21].Wijaya, P. D. and Ariana, I. M. (2009). Rancang Bangun Sistem Penginjeksian Gas Pada Modifikasi Gas-Oil fuel Diesel Engine, pp. 1-6.

[22].Ehsan Md, Bhuiyan. (2009). Gas-Oil fuel performance of small diesel for application with less frequent load... International Journal of Mechanical and Mechatronics Engineering (IJMME). Volume 9 (10), pp 30-39.

[23].Zoltowski A., (2014), Investigation of combustion process in GasOil fuel diesel engine, Journal of KONES Powertrain and Transport, Volume 21, no 2, pp. 303-309.

[24].Wei, L. and Geng, P. (2016) A review on natural gas/diesel GasOil fuel combustion, emissions and performance, Fuel Processing Technology. Elsevier B.V., 142, pp. 264-278. doi: 10.1016/j.fuproc.2015.09.018.

[25].Semin, Cahyono B. Amiadji. Bakar R.A. (2014). Air-fuel mixing and fuel flow velocity modeling of multi holes injector nozzel on CNG marine engine. Procedia Earth and Planetary Science 14. 101-109.

[26].Shrirao P.N., Sambhe R.U., (2012). Effect of Swirl Induction by Internally Treaded Inlet Manifolds on Exhaust Emissions on Single Cylinder (DI) Diesel Engine, International Journal of Science and Research, Vol 3 (7), pp 1718-1722.

[27].Zhang Q. ; Li M. Shao S., (2015). Combustion process and emissions of heavy duty engine fueled with directly injected natural gas and pilot diesel.

[28].Zhang, H. and Mastorakos, E. (2017) Modelling local extinction in Sydney swirling non-premixed flames with LES/CMC, Proceedings of the Combustion Institute. Elsevier Inc., 36(2), pp. 1669-1676. doi: 10.1016/j.proci.2016.07.051.

[29].Sahoo B.B. ; Sahoo N. ; Saha U.K., (2009). Effect of engine parameters and type of gaseous fuel on the performance of dualfuel gas diesel engine - A critical riview, Renewable and Sustainable Energy Riviews, Volume 13, pp 1151-1184.

[30].Semin. A.R. Ismail. and R.A. Bakar., "Investigation of GAS Engine Intake Port Gas Flow Temperature Based on Steady-State and Transient Simulation”,. European Journal of Scientific Research 22 (3), 2008.

[31].Semin. A.R. Ismail. R.A Bakar and I. Ali, "Heat Transfer Investigation of Intake Port Engine Based on Steady-state and Transienttion”, American Journal of Applied Sciences 5 (11), 2008.

[32].Abdul Rahim Ismail. Rosli Abu. Bakar. Semin. and Ismail Ali, "Computer Modelling for 4-Stroke Direct Injection Diesel Engine,” Advanced Materials Research, Volumes 33-37, 2008.
[33].A.R. Ismail. R.A. Bakar and Semin. "An Investigation of Valve Lift Effect on Air Flow and CD of Four Stroke Engines Based on Experiment.”, American Journal of Applied Sciences 5 (8). 2008.

[34].Semin. R.A. Bakar and A.R. Ismail., "Investigation of Diesel Engine Performance Based on Simulation”, American Journal of Applied Sciences 5 (6), 2008.

[35].Semin. R.A. Bakar and A.R. Ismail. "Computational Visualization and Simulation of Diesel Engines Valve Lift Performance Using CFD”. American Journal of Applied Sciences 5 (5). 2008.

[36].Semin. A.R. Ismail and R.A. Bakar, "Comparative Performance of Direct Injection Diesel Engines Fueled Using GAS Based on GTPOWER Simulation”, American Journal of Applied Sciences 5 (5), 2008.

[37].R.A. Bakar. Semin and A.R. Ismail, "Fuel Injection Pressure Effect on Performance of Direct Injection Diesel Engines Based on Experiment”, American Journal of Applied Sciences 5 (3), 2008.

[38].R.A. Bakar. Semin. A.R. Ismail and I. Ali, "Computational Simulation of Fuel Nozzle Multi Holes Geometries Effect on Direct Injection Diesel Engine Performance Using GT-POWER", American Journal of Applied Sciences 5 (2), 2008.

[39].Semin. R.A Bakar. and A.R. Ismail., "Compressed Natural Gas as an Alternative Fuel for Internal Combustion Engines: A Technical Review”, International Review of Mechanical Engineering Vol. 3 (2), 2009

[40].Semin. A. Idris, and R.A Bakar, "Effect of Port Injection GAS Engine using Injector Nozzle Multi Holes on Air-Fuel Mixing in Combustion Chamber”, European Journal of Scientific Research 34 (1), 2009.

[41].Semin. A. Idris. and R.A. Bakar, "An Overview of Compressed Natural Gas as an Alternative Fuel and Malaysian Scenario", European Journal of Scientific Research 34 (1), 2009.

[42].Semin. A.R. Ismail. and R.A. Bakar, "Gas Fuel Spray Simulation of Port Injection Compressed Natural Gas Engine using Injector Nozzle Multi Holes”, European Journal of Scientific Research 29(2), 2009.

[43].Semin, A. Idris. R.A. Bakar. A.R. Ismail., "Study of the Engine Cylinder Fluid Characteristics for Diesel Engine Converted to GAS Engine”, European Journal of Scientific Research 26 (3), 2009.

[44].Semin, A.R. Ismail. and T.F. Nugroho., "Experimental and Computational of Engine Cylinder Pressure Investigation on the Port Injection Dedicated GAS Engine Development”, J. Applied Sci.10 (2). pp: 107-115, 2010.

[45].Semin, "Injector Nozzle Spray on Compressed Natural Gas Engines: A Technical Review", International Review of Mechanical Engineering 6. (5), 2012.

[46].Semin, RA Bakar, Simulation and experimental method for the investigation of compressed natural gas engine performance", International Review of Mechanical Engineering 7 (7) , pp. 1427 (7), 1427, 2013

[47].Semin and R.A. Bakar, "Computational Modelling the Effect of New Injector Nozzle Multi Diameter Holes on Fuel-Air Mixing Homogeneous of GAS Engine”, International Journal of Applied Engineering Research. Volume 9 (21). pp. 9983, 2014.

[48].Semin, "Analysis of Biogas as an Alternative Fuel for Electric Generator Engine in Bawean Island - Indonesia", International Journal of Applied Engineering Research 10 (16). pp. 3531335317, 2015.

[49].Semin, "Investigation the Effect of Injector Nozzle Multi Holes Geometry on Fuel Spray Distribution Flow of GAS Engine Based on Computational Modeling”, International Journal of Applied Engineering Research 10 (15). pp.36087-36095, 2015.

[50].Semin, B Cahyono, Amiadji, RA Bakar, "Air-fuel Mixing and Fuel Flow Velocity Modeling of Multi Holes Injector Nozzle on CNG Marine Engine”, Procedia Earth and Planetary Science 14, $101-109,2015$.

[51].H Prastowo, Semin, MB Zaman, Amiadji, TB Musrijadi, A Santoso, "Investigation of Fuel Flow Velocity on CNG Engine using New Injector", Asian Journal of Engineering and Technology 4 (2), 38 - 43, 2016.

[52].Mansor, W. N. (2014). Gas-Oil fuel Engine Combustion and Emissions - an Experimental, p. 162.

[53].Yerrennagoudaru, H. and prasad Desai, S. (2015). Generation of Air Swirl through Inlet Poppet Valve Modification and To Enhance Performance on Diesel Engine, IOSR Journal of Mechanical and Civil Engineering, 12(6), pp. 2278-1684. doi: 10.9790/1684-12665465. 